\title{
IN THE INTEREST OF THE STATE: Production Politics in the Nineteenth Century Prison
}

\author{
WILLIAM G. STAPLES \\ University of Kansas
}

\begin{abstract}
During the nineteenth century, the jails, penitentiaries, and reformatories of America were "industrialized" under both public and private production regimes. Society-centered revisionist writing in both sociology and history has failed to explain adequately the appearance, consequence, and ultimate dismantling of these regimes. In this paper I offer an alternative, state-centered analysis which locates the political state within its interdependent relationship with the economic and normative spheres of society. My view underscores the role of state managers and agents as historical subjects whose actions have consequences for the structuring of the state apparatus.
\end{abstract}

The history of public policy in the United States concerning the control of the criminal, the deviant, the idle, and otherwise troublesome populations has been a cyclical one of "reforms," "innovations," and "solutions." Until recently, reformist historiography assessed these policy movements as the result of shifts in ideological currents, often stressing the actions of benevolent, forward-thinking progressives in shaping a more humane social world (cf. McKelvy [1936] 1977; Schneider and Deutsch 1941; Zilboorg and Henry 1973). This was a history of progress, a history of unquestionable allegiance to scientific humanism and social intervention. Today, a body of "revisionist" sociology and history challenges this perspective with a "determination to locate the reform enterprise in the social, economic and political context of the period" (Cohen and Scull 1983:2). ${ }^{1}$

While revisionist writers have taken us beyond the "history of progress" paradigm, they have yet to offer a systematic analysis of the role of the state in the historical transformation of institutional control practices-referring narrowly to those activities, from imprisonment to mental hospitalization, by which certain populations are removed from the everyday life of society. ${ }^{2}$

Direct all correspondence to: William G. Staples, Department of Sociology, University of Kansas, Lawrence, KS 66045-2172. BITNET: staples@ukanvm. 
Paradoxically, this situation exists despite the fact that many take the centrality of the state as a given. As one group of authors recently put it, "It is obvious that a theory of the state must be central to any analysis of social control in . . . capitalist societies since the state has assumed direct responsibility for supporting the institutions of control" (Lowman, Menzies, and Palys 1987:5). And yet, many writers, in their attempt to unearth the "real" basis of social control policies, have lost sight of the day-to-day realities of the state and the interests of those who administer these "institutions of control."

In actuality, revisionist writers have offered "society-centered" rather than "state-centered" inquiries. Within society-centered analyses-whether pluralist, liberal, or Marxist-society is the initial and principal object of inquiry and the state is derived from or reduced to an arena of competing interest-group politics, a reflection of class relations, and the like. ${ }^{3}$ Alternatively, more "structural" perspectives on the state have portrayed its existence and function as taking place "behind the backs" of actors. That is, action, and hence human agency, is reduced to structural "adjustments" or the "imperatives" of capitalist production. This society-centered revisionism is reflected, for example, in what little contemporary writing there has been on the development and use of penal labor in the nineteenth century. Here the questions that remain at issue are: why was it that, during this period, many prisons came to resemble the factory? That is, why did the organization of penal labor-based on commodity as well as agricultural production - mimic capitalist organization in work, time, discipline, and profit motive? ${ }^{4}$; whose interests did this resemblance serve?; and, finally, what accounts for the ultimate failure of the state to "industrialize" correctional facilities with the aid of private capital?

For Melossi and Pavarini ([1978] 1981), for example, what they call the "prison/factory" emerged not out of economic utility, but rather as a "disciplinary apparatus" with a human product to produce. The authors state that the genuine aim of prison labor was

the transformation of the criminal into proletarian. Thus the object was not so much the production of commodities as the production of men. From this point of view we can see the real dimension of the 'penitentiary invention:' a prison as a machine capable of transforming, after close observation of the deviant phenomenon, ... . the violent, troublesome and impulsive criminal (real subject) into an inmate (ideal subject), into a disciplined subject, into a mechanical subject" (1981:144, emphasis mine).

Here the authors attempt to link the prison and the use of prison labor to the rise of capitalism, its work organization, and the reproduction of class relations. They argue that the inability of officials to turn the prison into a viable factory was the result of the disenchantment of private capital with the venture on the one hand, and organized working-class resistance on the 
other (1981:142). The role of the state and the interest of state managers, however, goes unexamined, essentially reduced to a managerial, if not implicitly instrumental role, in the reproduction of a bourgeois social order.

In a similar yet broader analysis, Foucault ([1975] 1979), argues that the economic effect of prison labor is not in the activity of production itself but that by "producing individuals mechanized to the general norms of an industrial society. ... [it constitutes] a power relation, an empty economic form, a schema of individual submission and of adjustment to a production apparatus" (1979:242-243, emphasis mine). Rather than an instrument of a particular class, however, Foucault sees the prison and its correctional apparatus as an extreme form of a disciplinary savoir permeating the entire social formation. Given the sweeping and abstract nature of Foucault's project, however, the state remains in a shadowy and undertheorized position. Finally, in Rothman's (1980) view, prison labor is interpreted as a practical and generally popular enterprise with reformers, the public, administrators, and legislators, each having a different vested interest in its successful operation. While Rothman underlines the importance of prison labor for state managers, his emphasis is on drawing out the internal paradoxes of this activity: the tension between "conscience and convenience." But I would argue that a more robust explanation must also locate changes in the use of correctional labor within the broader political and economic arena and the shifting boundary between the state and civil society.

My purpose in this essay is to reinterpret the history of prison labor schemes within an alternative, state-centered perspective. This view acknowledges a distinct political sphere in society with a separate yet structurally interdependent relationship to the economic and normative spheres. Further, I analyze state action within the context of contradiction and crisis management and explicitly assume that state managers have, with few exceptions, an institutionalized self-interest in the reproduction of both the state and the wider social formation; a dual investment which must be constantly negotiated under changing historical contexts. ${ }^{5}$ Thus, rather than reducing the state to an arm of the ruling class, or characterizing it as a lifeless reactive mechanism, this analysis seeks to focus on the political body in its own right as the vehicle of social policy. In this way, I account for the appearance, evolution, and eventual dissolution of prison labor schemes within the social structuring of the state apparatus. I first sketch a theoretical framework consistent with a state-centered analysis, and, second, I link these ideas to the specific problem of U.S. penological practice throughout the nineteenth century.

\section{STRUCTURE, AGENCY, AND THE STATE}

My analysis is guided by a number of theoretical issues concerning the development of the modern state. This agenda centers on the questions of the historically specific form the state takes, the functions or activities it 
engages in, and mechanisms or apparatus through which functions are executed (Clark and Dear 1984). The question of form addresses how and why a specific state is constituted by, and evolves within, a given social formationin this case, nineteenth century American liberal-capitalism. ${ }^{6}$ In actuality, we see the development of two liberal-capitalist state forms during this period, involving three primary functions: (1) securing social consensus by guaranteeing the acceptance of the prevailing contract by all social groups; (2) ensuring conditions of economic production and social consumption; and (3) and providing a minimum degree of social integration by guaranteeing the general welfare of all groups. The first state form (roughly 1790-1860) was the "Accumulative State," a transition state, reflecting a compromise between the new liberalism and the old order, which took an active role in ensuring economic development and establishing public order until about $1860 .^{7}$ Like many "new" states, a claim to legitimate political authority depends on demonstrated effectiveness in these areas.

State intervention for the sake of economic development took a number of direct and dramatic forms during the period. The most striking examples were in state financing, the creation of "mixed" public/private enterprises, and in assuming direct ownership of much of the country's transportation, banking, and even of some large commercial enterprises. ${ }^{8}$ These activities had specific consequences for the organization of penal institutions, the state's primary response to the problem of public order. The Accumulative State, then, was an interventionist state. It extended itself into diverse social and economic arrangements, creating the basis for both economic development and the conditions of its own reproduction.

The second state was the "Bureaucratic State" (roughly post-Civil War to about 1915), a reformist state which resulted from the success of the Accumulative State. That is, with economic development and industrialization came sharper class divisions, recurring economic depressions, and, with them, problems of legitimation. The period was characterized by a strong laissezfaire ideology, the rise of both organized capital and labor, and eventually, muckraking journalism and social and political reform. This reform movement attacked the corruption of party patronage or the "spoils" system, advocating revision of civil service procedures and accountability. Such "rationalizing" reforms were intended to make the administrative structure of the state more efficient and manageable. Building social consensus and securing social integration became primary functions of this state form. ${ }^{9}$

I view the penal system as part of the state apparatus or the set of organizations and institutions through which state power is exercised and state objectives are realized. The various agencies of the state represent the concrete form of state power; as such, they constitute a bureaucratic medium which necessarily shapes and transforms the actual exercise of state power. Once established, such organizations may take on a logic and interest of their own, creating a "slippage" between their intended function and existence. Moreover, as a concrete form, the policies and activities of the apparatus are 
vulnerable to being influenced by outside groups with their own agenda. Here we may observe sequences of alliances-more or less temporary and policy specific-between the state managers and those groups outside the state over the policies exercised by the apparatus. Thus, not only must we explore the relationship between these institutions of the state and state functions, but we must comprehend their own internal organizational logic and inertia, the extent to which they mediate the exercise of state power, and their relationship to civil society.

Therefore, I want to locate my assessment of nineteenth century penological practice within the policy-making capacity of the state itself. My argument is that attempts by state governments to "privatize" the industrial operation of the penitentiary were consistent with the functional objectives of the Accumulative State form. Yet embedded in such activities are contradictions or the unintended consequences of social action. ${ }^{10}$ That is, both the form of a given state and the functional objectives of consensus, production, and integration are not necessarily congruous, but rather are potentially contradictory. For example, while the liberal-capitalist state must "crisis manage" social and economic development, it is, by definition, a state form which is restricted through legal, political, and cultural norms from "interfering" in civil society. The functions of the state may operate at cross-purposes as state managers attempt to balance competing political claims. For example, repressive tactics aimed at ensuring consensus may alienate certain groups and thereby threaten integration and political legitimacy. The state apparatus exhibits internal, contradictory tendencies as well. Here organizations may take on their own inertia, perpetuating the interests of those who manage them rather than adapting to new policy directions. Further, the apparatus may consume increasing amounts of state resources, thereby creating potential fiscal crises (O'Connor 1973).

The logic of my theory/method is that the contradictions and the unintended consequences of state action, engender new problems requiring further action but under new historical circumstances. Thus, subsequent policy initiatives reflect adjustments to the accumulated contradictions of past actions and the attempts by state managers to balance their objectives with the material, legal, and administrative capacity available to them. A history of the nineteenth century penitentiary recounts the evolution of a particular state apparatus, while illustrating the relationship between the form and function of the liberal-capitalist state, and reveals the struggles of state managers attempting to cope with the unintended consequences of the past while reproducing the state and their positions in the present.

\section{THE "PROBLEM" OF PRISON LABOR}

It cost Americans little to incarcerate criminals in the immediate post-Civil War period (Mohler 1925; Mittleman [1921] 1966; Rothman 1980). Most responsible was the use of inmate labor to defray costs. In fact, penal labor 
contributed to minimal outlays and balanced books and, in some cases, produced profits between roughly 1830 and the 1880s (Commons [1921] 1966). However, by this time, penologists, criminologists, legislatures, and the public were engaged in a debate about the conditions under which prisoners would work. Few questioned the notion that prisoners should work-that was a given. As one participant at the National Prison Association meetings of 1883 stated, "I take it for granted there are no gentlemen in this room that do not hold to the idea that there must be labor in prison. It is simply a matter of labor, or supporting the convicts in idleness" (National Prison Association [NPA] 1884:183). Two years later, a Chicago Correctional Superintendent stated in his address to the Association:

We are here today as scientists, reformers and business men. As such, in a
trio sense, we are to discuss Prison Labor. We are agreed, that the physical
employment by criminals is essential to their health, happiness, and reform.
$\ldots$. . But we are not agreed as to the system of employment. . . . Economic
questions largely control our views (NPA 1887:217).

Indeed, the debated question of the 1880 s concerning prison labor was under which system of production the work would be organized. By 1885, roughly five production "regimes" (Burawoy 1983; Staples 1987) existed for organizing the labor of America's penal systems. ${ }^{11}$ According to the Bureau of Labor Statistics these were: (1) the lease, (2) the contract, (3) the pieceprice, (4) the state-account, and (5) the state-use system (U.S. Bureau of Labor Statistics 1925). While the adoption of a particular regime reflected the political and economic history and circumstances of a particular state (and multiple systems often co-existed within the same state), the proportion of inmates involved in each production system varied considerably over time. A state-centered analysis suggests that the establishment of the lease, contract, and piece-price arrangements reflected various alliances created by state managers with a segment of private capital in order to confront the problematic nature of institutional policies for the liberal-capitalist state.

Under the lease system, inmate labor was sold to the highest bidder for a fixed period. The state abdicated all responsibility for prisoners to the lessee, including the provision of food, shelter, and control. The system became widely adopted throughout the United States, and particularly in the South, as a substitute for African slavery in agriculturally-based production schemes. The contract system was similarly embraced by prison authorities. Under this regime, inmates toiled within the walls of the prison in factory shops which were set up by the administration, but were run by outside contractors and their foremen. The contractor supplied the raw materials and paid the state a fixed rate for every day worked and for the number of prisoners employed. The piece-price, a variation on the contract scheme, was adopted in only a few states. Here the state retained complete control over the labor 
process. The contractor provided the raw materials and manufacturing specifications but had no employees within the walls of the institution. Inmate labor was sold by the number of pieces produced.

Finally, two solely public arrangements were the state-accounts and stateuse systems. Under the state-accounts model the state assumed "the role of the entrepreneur . . . entering fully into business with all its risk and uncertainties" (Robinson 1931:95). The state incurred capital costs, procured raw materials, organized and controlled the labor process, and marketed and sold the final products. The state-use scheme was identical to the stateaccounts system with the exception that prison-produced products were not sold on the open market. Rather, goods and services provided by inmate labor were used within the institutions themselves or were consumed by state agencies. Public works projects benefited from this arrangement as inmates were used in the construction of roads, railways, public buildings, and even other prisons.

In order to understand the debates of the 1880 s concerning the varied use of these production regimes, it is essential that we understand how and why they developed, consider the conditions under which they were employed, and reveal the contradictions that undermined and changed them. In doing so, I wish to demonstrate how state managers initiated these various prison labor schemes in an attempt to balance their own administrative, fiscal, and legitimation problems and how and why this extension of state power ultimately failed as public policy.

\section{THE ORIGINS OF THE PRISON AS "FACTORY"}

The American prison emerged as a "republican machine" (Dumm 1987), constitutive of liberal democratic values and founded on the assumption that the state possessed the power to deny an individual's freedom. Laboring within the walls of America's penal institutions dates from the Colonial period (Ives 1914; Mohler 1925; Lewis [1922] 1967; Rothman 1971). ${ }^{12}$ The notions of "hard labor" and penal servitude were grounded in moral, legal, practical, and, as time went on, increasingly economic foundations. As a representative of the Philadelphia Society for Alleviating the Miseries of Prisons, a reformist organization rooted in Quakerism, urged before the state legislature in 1788, "solitary confinement to hard labor and a total abstinence from spirituous liquors will prove the means of reforming these unhappy creatures." "All prisons should be workhouses," they declared, as the basis for both punishment and reformation. ${ }^{13}$

By 1790, Pennsylvania had stipulated in its penal code that prisoners would work in the recently erected cell house of the Walnut Street jail. By engaging their charges in labor, jailers could count on a more disciplined environment, while the products derived from the inmates' labor would offset the cost of confinement. At Walnut Street, prisoner accounts were debited for the cost 
of clothing, upkeep, and raw materials. To "encourage industry as evidence of reformation" their accounts were credited with the proceeds of their labor, and, if there was an excess over costs, they were to receive half upon their release (Barnes 1927:164). Few among prison officials and politicians expected a profit from the institutions at this time; Massachusetts Warden Bradford called his prison a "benevolent institution" deserving of state support (Hindus 1980:164). Prisons had few marketing links to the outside for their products, the labor process was based on handicraft production, and the intended purpose of forced labor was one of deterrence, reformation, and control rather than profit maximization. Virtually all prisons were run on publicaccounts systems.

During the first three decades of the nineteenth century, the United States experienced dramatic population growth and urbanization. Between 1790 and 1830, the nation's population more than tripled from nearly four to almost thirteen million. By 1830, half a million people lived in urban areas with populations exceeding fifty thousand residents (U.S. Bureau of the Census 1960:12-14). In Philadelphia, the transfer of felons from rural counties had the effect of swelling the numbers in the Walnut Street jail and soon the moral regime of solitary, hard labor, diet control, and hygiene was in disarray. Eventually, conditions at the jail erupted into a political crisis for the state legislature as jail inspectors began pardoning prisoners to alleviate overcrowding. Moreover, abuses and neglect were exposed and serious riots took place in 1817, 1819,1820, and 1821. In the uprising of 1820 , nearly the entire prison population escaped (Barnes 1927:155).

The result was condemnation of the Walnut Street jail by the Philadelphia Society for Alleviating the Miseries of Prisons. This denunciation was summarized in a Report of the Commissioners on the Penal Code which stated that conditions had caused the prison of Philadelphia to "forfeit the high character it once possessed, and to become a reproach to the city in which it was located, and to the state by whom it ought to be superintended. ${ }^{\prime \prime 4}$ The ideals of liberal-democratic discipline had confronted the day-to-day realities of the liberal-capitalist state. Yet, rather than change direction, the state pressed on and influential people in and out of the state called for the building of new penitentiaries. Undertaking the most ambitious public works program in Pennsylvania's history to date, the Western and Eastern facilities were erected by the laws of 1817 and 1821, marking the beginnings of the state's prison "system" and thus a major expansion of its penal apparatus. Both institutions adopted handicraft production within cells, by law, in 1829.

The situation was similar elsewhere as other states increased their commitment to institutional punishment. Such expansion, however, only increased the already deficit-ridden prisons. According to Mittleman ([1921] 1966), in addition to construction costs, the Philadelphia prison operated at an average annual loss of $\$ 30,000$, and in New York, from 1797 to 1821, the state prison at New Gate ran an average annual loss of just under $\$ 17,000$. At the 
first New Jersey state prison at Trenton, losses in the 1820 s ran $\$ 3,000$ to $\$ 4,000$ annually. In fact, the prison cost the state $\$ 165,000$ over thirty years, one-third the total state tax revenues for the period (Barnes 1918:72). With the rise of the merchant-capitalist class, the expansion of markets, and a shortage of cheap labor (prior to the massive immigration of the mid-1800s), the prison became an attractive setting for the developing industrial model. Meanwhile, prison and state officials were looking for ways of deferring rapidly increasing costs. The implications were clear:

In the late twenties and early thirties, a re-organization in the prisons took place and the modern prison system was launched ... Instead of working them [inmates] in small shops under 'mutual inspection,' large shops were erected in the prison court yards where supervision and discipline were easy. 'A single overseer,' says the Boston Prison Discipline Society, describing the new shops at the Massachusetts prison, 'really does more to prevent evil communication between one hundred men in this shop, than ten overseers in ... the old brick building.' Instead of manufacturing on their own account, the prisoners were now let out to contractors (Mittleman [1921] 1966:345).

In 1819, three years after its construction, and by order of the state legislature, the New York penitentiary at Auburn was the first to adopt the new system of contracted, "joint labor" by day, and solitary by night. Auburn turned a profit by $1828 .{ }^{15}$ A keeper there stated: "great risk and losses are avoided, and much private capital, and personal interest and enterprise, are brought into action, in promoting the active and profitable employment of the convicts" (Mittleman [1921] 1966:346). Since prisoners worked in congregate shops during the day and were confined to cells only at night, the Aurburn plan, it was argued, afforded lower construction costs and a more efficient use of space. The less time prisoners spent in isolation, the smaller and more austere the cells could be, and the constant surveillance provided by the centralized production not only prevented "evil communication," but more important, ensured strict control and discipline over the labor process. This regime was embraced in many states; soon to follow were Connecticut, Ohio, Maine, New Hampshire, and Vermont. After all, state governments were actively involved in "mixed" (public/private) economic ventures in other spheres, why not also in the prison? By merging the domain of state control with the interest of private capital, the state had created a unique social form; indeed, a new form of state apparatus and a reconstitution of state power.

In contrast, the Pennsylvania penitentiaries refused to adopt the new methods (although they did, on occasion, "yield to temptation," according to Barnes [1927:240], and engage in piece-price arrangements). Dedicated to the notion that inmate labor was primarily for purposes of reformation and not profit, officials debated the ethics of prison labor with their colleagues. 
Steeped in the reformist and philanthropic philosophy of the early Quakers, the argument of some Pennsylvania officials was that the state and society were best served when the penal apparatus produced, as Beaumont and Tocqueville put it, the "deepest impression on the soul of the convict" (1833:59), rather than be concerned with what they considered short-term interests of cost. At the Eastern facility outside Philadelphia, Inspector Richard Vaux voiced again and again throughout his long career his objections to the Auburn system of factory production. For example, in 1855, he stated:

The labor here, is not farmed out as in some State Penitentiaries. . . . The prison authorities, by the operation of this [Auburn] plan, have a divided duty. They are bound to the contractor for the labor he exacts for his per diem paid for each convict. This is the most important interest. The care of, and the discipline, and the reformatorial influences which ought to be faithfully exerted for the benefit of the convict, as well as society, being less palpable when in contrast with revenue, it might most naturally happen that the contractor is favored to the detriment of the convict. ${ }^{16}$

And later:

It is believed that the congregation of convicts during their incarceration for crime-punishment, and their sale to the highest bidder as human machinery, out of which profit is to be made, is of far greater evil to society, than society yet fully comprehends. ${ }^{17}$

Steadfast in their resolve, Eastern Penitentiary officials argued the virtues of their system before their lawmakers. In 1837 they stated:

The Inspectors assure the Legislature, that if permitted to develop itself fully, under the fostering influence of that policy which has always been extended to it by the Legislature, that the time is not far distant, when the Penitentiary system of our State, will be regarded among the proudest monuments of the wisdom of her people. ${ }^{18}$

Apparently persuaded by the inspectors' arguments (and seriously constrained since the structure of the facility would not permit congregate shops), the state continued to support and subsidize the Eastern facility. And pay they did. Year after year the institution posted deficits. As Barnes (1927:287) put it:

Never in its history has the Eastern Penitentiary failed to be a burden upon both the state and counties ... [it] was wholly comparable to the many pathetic cases in the last century where handicraft artisans maintained a proud but losing and hopeless competition with the irresistible march of mechanical invention and labor-saving machinery. As time went on ... the struggle became palpably disastrous in a financial sense. 
The case of New Jersey demonstrates the forces that ultimately settled the debate over the system of prison organization. In this state, the apparent failure of the first state prison-both in terms of its supposed deterrent capacity and its cost-prompted an investigation by a joint committee of the legislature in 1830 which concluded "with entire unanimity the building of a new prison, on the general plan of those at Auburn, New York." 19 Yet, by 1833, both the legislative committee and the governor had changed their position to support the Eastern Pennsylvania model rather than the Auburn plan. The committee, in outlining its advocacy of the Pennsylvania system of solitary confinement and labor, argued that the "great terror" known to have been "impressed upon the minds of the convict community by this Institution [would] . . . hold out the most powerful repellant to the commission of crime" within the state. ${ }^{20}$ The committee contended that concern for profits must be held "subsidiary to the great ends of punishment," although at the same time they assured the legislature that within the Eastern facility "a convict can in six months earn his maintenance." The new state prison with solitary confinement for 150 convicts was opened in 1836 at the cost of $\$ 179,429$. Yet just four years later, the prison cost nearly $\$ 16,000$ annually to operate. From 1841 to 1858 a piece-price contract system was installed and the debt reduced to $\$ 1,000$. Actions by the governor and the legislators in the early 1860s expanded congregate workshops and permitted the leasing of inmate labor to private contractors, thereby adopting, if not in name but in spirit, the Auburn system.

Interestingly, at Pennsylvania's Western Penitentiary, administrators were less enamored with the handicraft, state-accounts regime of their Eastern counterparts. As early as 1836 the inspectors, who were responsible for overseeing the industrial production of the prison, complained of the lack of efficiency of the solitary system. By the 1860 s their attacks were increasingly vigorous. "Discard your cell labor," they declared, "change your separate system and adopt the congregate, and you will be able to use the muscle and skill of the prisoner much more to the advantage of the Commonwealth." ${ }^{\prime 21}$ Conditions were ripe for the changeover as the post-Civil War era brought increased populations, an industrial depression, overcrowding, and a bleak financial picture for the prison. In 1866, the inspectors argued that the legislature had two choices: adopt the new system or build new cells to support the solitary system. In 1873, a contract system of congregate shops with mechanized production was installed at the Western Penitentiary. Clearly, one contradiction embodied in the Pennsylvania system was the fiscal pressures it brought politicians; there can be little doubt that this contributed to its unpopularity and eventual demise.

With the exception of the Eastern Penitentiary of Pennsylvania and, for a short period of time, the New Jersey system, private contractors, either under the contract, lease, or piece-price regimes, dominated prison industries from roughly 1830 to the postbellum period. It would seem that the 
vast majority of state managers had, by adopting the Auburn system, successfully intervened and responded to the potential problem of the "dangerous classes." They created social consensus by securing order and stability in society, permitted the protection of commerce in accordance with civil law and thereby ensured conditions of private production. Moreover, by forging an alliance with a segment of private capital, state managers were able to defer the financial cost of expanding the state apparatus. They had, in essence, successfully reproduced the conditions of their existence and legitimation. As Rothman (1980:27) notes:

All the parties liked the arrangement. The state had the guarantee of an income without incurring risks or capital costs: it was the contractor that supplied the machinery, the goods and the supervisory personnel. In return the contractor had a cheap supply of labor for manufacturing goods to be sold on the open market. ... So in effect, state legislatures and taxpayers had little cause to quarrel with the financial aspects of criminal incarceration. Costs did not run counter to the convenience of confining offenders.

Yet the situation was not without problems. As early as 1823, "free labor" had expressed its objection to the sale of prison-made goods. In that year, cabinetmakers, engineering workers, and an ad hoc Workers Commission in New York complained of unfair competition (Commons [1921] 1966; Gill 1931). In 1834, trade unions forced the appointment of a special commission by the legislature of New York to investigate the problem. The workers demanded an end to the contract system. The commission offered modifications in the conditions of contracts, but would not yield the contract system, concluding that prison work had to be productive in order to offset costs (Mohler 1925; Commons [1921] 1966). Given the relatively weak political position of trade unions at this time, legislators had little incentive to restrict the contract system.

In the period just after Reconstruction, more organized and powerful national trade unions and, possibly more important, manufacturers, launched a forceful attack on convict labor. The industrial depression of $1873 \mathrm{had}$ thrown millions of "free" laborers out of work while markets for prison goods dried up. Union organizations such as the Knights of Labor and the Federation of Organized Trades and Labor Unions carried anti-contract motions into the political arena. In 1883, the Tennessee Coal, Iron and Railroad Company hired 1,300 convicts from the state penitentiary in order to force wage concessions from miners. Conditions there deteriorated and, in 1891 , the free miners burned down the camp, freeing the prisoners. Only after a violent confrontation with the state militia was the leasing of convicts outlawed.

The system was equally denounced by those manufacturers who were not taking advantage of low-priced prison labor. While the total value of produc- 
tion of prison industries had a minor impact on the free market system as a whole, it had a considerable impact within certain industries, e.g., boots and shoes, twine, furniture, and the like. At its convention in 1878, the Hatmakers' Association, for example, voiced its objection to the dissolution of business due to the use of prison labor in private shops. Moreover, public sentiment began to turn as corruption and bribery were exposed and the despotism of private contracting took its toll on prisoners/workers. Reports of extreme cruelty, miserable working conditions, and deaths began to surface, particularly in the South's notorious "chain-gang" and agricultural lease systems. In Texas alone, for example, 224 inmates died between the years 1886 and 1888. Rothman (1980:137) states that "while some of the deaths could be explained away because Negroes ostensibly were already carrying 'the seeds of disease,' state inspectors agreed that at least some of the contractors . . . [were] 'guilty of inhumane treatment. "'22 The "successful" alliance created by state managers was crumbling .

The "crisis" of convict labor did not go unnoticed by politicians seeking office who, according to McKelvy ([1936] 1977:117), "had their ears to the ground in the early eighties, and they revealed some ability at realpolitik if not in penological statecraft." During that time, the Democrats, with aid of the labor vote, took control over influential state governments and eventually the White House. By the end of the decade an onslaught of legislation arose restricting the "private" systems of contract labor and requiring some form of public-accounts system. In addition to appeasing organized labor, these "reforms" were part of a wider movement to cleanse the apparatus of the spoils system of political appointments to prison administrations and their links to private contractors.

While most industrial states, like Pennsylvania, were quick to outlaw private contracting (1883), the practice persisted in other states until the 1930s. Nevertheless, the shift toward direct public control was dramatic. In 1885, only five states operated exclusively and eleven partially under publicaccounts systems (U.S. Department of Labor 1887; U.S. Bureau of Labor Statistics 1925). By 1923, the figures were 30 and 18, respectively, with the latter having some private system in place. The lease system, which accounted for 26 percent of the total value of goods $(\$ 24,271,078)$ in 1885 was gone completely; public-works accounts now represented 20 percent of the 1923 goods value of $\$ 73,820,125$, up from one-tenth of one percent; and stateuse increased from 8 to over 37 percent of total value. Still pressured by ever-increasing costs and the need for discipline in the institutions, state managers turned to public-accounts systems as a compromise, but they were no substitute. As Gill (1931:88) points out,

it should be noted that while the number of convicts employed in productive labor increased from 30,853 in 1885 to 51,779 in 1923 , or 70 percent, the number engaged in prison duties, sick, and idle, increased from 11,024 to 
32,962 or 199 percent. . . . It appears that idleness increases as public control increases. Indeed, state-use and public-accounts systems were failures at generating revenue.

A survey of prison industries by Robinson (1931:235-245) covering the late 1920 s concludes that, "It is plain that the great majority of American prisons not only fail to meet operating costs but require heavy annual appropriations." By 1929, the passage of the Hawes-Cooper Act, a congressional bill lobbied by the Garment Manufacturers' Association, severely restricted the interstate flow of prison goods by subjecting their sale to the laws of the state in which they were sold. After its passage, state after state enacted legislation prohibiting the sale of convict-produced goods from other states. With the onset of the Great Depression, and millions outside the penitentiaries unemployed, the issue of prison labor disappeared from the national agenda.

\section{IN THE INTEREST OF THE STATE: DISCIPLINE, PUNISHMENT, AND CAPITALISM}

Why was it, then, that the public prison came to resemble the private factory; whose interests did this resemblance serve, and why did the associated practices ultimately fail? Was the "real" intention the production of proletarians as Melossi and Pavarini ([1978] 1981) contend? I would argue that there are considerable problems with this point of view which is narrowed by instrumentalism and functionalism. Who, for example, is the historical agent in this account? The "bourgeoisie," as the authors contend? If so, why did manufacturers join the fight against prison labor, a fact curiously left out of their narrative? To assume that the essential role of the prison was the disciplining of the working-class is to characterize the institution as a tool placed squarely in the hands of an united class motivated by a definable agenda. Moreover, to make such an assumption places the state in an equally instrumental position, and thereby denies the institutional self-interest of the state, and neglects to consider the ways in which such self-interest shapes public policy.

As for Foucault's assertion that penal labor constituted an "empty economic form," ([1975] 1979:243) even a cursory reading of the reports of prison officials for the period affords clear evidence that "successful" prison operations were the ones that cost the least. While the Auburn plan may have reflected more the norms of an industrialized society, it seems hardly a coincidence that the years in which it was most rigorously applied were also the years in which prisons produced the greatest profit.

Rothman's (1980:144) claim, on the other hand, that the failure of prison labor schemes reflected the inconsistency between the goals of reform and custodial care is quite true-at the level of the penal apparatus. However, his explanation falls short by not linking the enterprise to the state and the principles governing its own existence. 
My contention is that the nineteenth-century American penitentiary did contain a goal of economic utility and this goal reflected this interest of state managers attempting to reproduce their position within the political structure. Thus, the prison came to resemble the factory because it was in the interest of state officials to extend the power of the state by creating a cooperative alliance with a segment of private capital. By doing so the state could, via its apparatus, accomplish its principal objectives of producing social consensus by confronting illegitimate behavior and of establishing order and stability. This, in turn, ensured general conditions of economic production (even within prison walls) and social integration by guaranteeing both collective security and the creation of social wealth. All these objectives helped to ensure the political legitimacy and material power of the early liberal-capitalist state. Thus, the state had the incentive to make prison labor as profitable as possible and, given the economic developments outside the prison, it had an interest in uniting private capital and its prison populations. In this case, politics at the level of the state intersected with the politics of production.

A number of unintended consequences emerged through this intersection and these contradictions brought about the demise of viable prison industries. First, at the level of the apparatus, the state linked the prison to the economic movements of capitalism outside the prison and, once so linked, it changed the character and the mission of the institution. For the majority of prison administrators, profitable regimes met their short-term goals of both discipline and managerial efficiency of the state apparatus. Thus, one consequence of this linkage was the dominance of economic activity in shaping both policy and life in the institution. As a critical report from the Eastern Penitentiary characterized this coupling:

To make a Penitentiary a manufactory in which all alike are worked together as part of a machinery of production, is incarceration with labor. The individual is lost sight of, uncared for, in the mass of all ages, sorts, and conditions of men. The man is unknown. As part of a machine he is recognized. ${ }^{23}$

A second consequence of transforming the prison into a factory was that, as a productive enterprise, it was drawn into the contradictions inherent in liberal-capitalist economies. Boom and bust business cycles left stockpiled goods unsold, while markets for particular products dried up. Since changes in shift work and "layoffs" were problematic, production went on regardless of outside market conditions. Moreover, the prisons had to compete with capitalists on the outside who were constantly introducing new machinery and methods to reduce labor costs or improve products. Not only was it difficult for prison industries to adjust to such changes, but the idea of introducing "labor saving" technologies into the prison environment reflected the flawed logic of the state prison as an unorthodox economic form.

Finally, and most important, production regimes were initiated during a period of the general acceptance of public/private "mixed" enterprises, the 
trademark of the Accumulative State form. Yet these arrangements were later viewed as trespassing the boundary between the state and civil society as that threshold was defined in the latter half of the nineteenth century. While the state had little to do with the actual operation of "privatized" systems (a considerable advantage to the state), the prison plant and, hence, the private contractor, benefited from cheap or free labor, as well as subsidized land and capital since overhead costs were derived from taxes rather than private expenditures. By providing such subsidies, the state was directly involved in organizing a production apparatus which was competing with free industry and labor. In the case of public systems, a purely state-financed and state-run organization was in complete violation of the "fair" rules of laissez-faire liberal-capitalism. As Inspector Vaux somewhat sarcastically put it in 1880:

an individual commits crime, is convicted, his physical capacity to toil is sold to a contractor who becomes a partner with the State in the manufacture of certain products, and from the sale of these products the State gets part of the profit, the contractor gets part of the profit; while the outside free laborer is paid as low a price for his free time and capacity, as his employer can afford, to come into competition with the State as a manufacturer. This is called punishment of the convict for his crime. ${ }^{24}$

In sum, when faced with rising prison populations and mounting deficits during the 1820 s, the majority of state governments turned to private capital to make prisons viable economic units. They had neither the tax base to support expanding prison systems nor the incentive to raise taxes. During this period, "mixed" enterprises were not uncommon and the political weakness of unorganized "free" labor permitted the state to initiate and subsidize production within the walls of prisons. This movement was justified, ideologically, by a historically-grounded notion that prisoners should work for their reformation, punishment, and keep. The movement contributed to a half-century of a politically and economically "convenient" use of institutionalization of the criminal element of society. By the 1880s, however, working-class resistance and organized capital had united with a reformist critique of abuses under the private system to create a new crisis of legitimation for state governments. In order to alleviate this crisis, the reformistoriented industrial states began taking control of production away from private capital, setting up state-account and state-use systems in an attempt to appease criticism while continuing to try to offset the cost of the penal apparatus. These systems, however, failed to be economically viable and by the 1930s, with the onset of economic crisis, states were forced to contend with prisons that were holding idle and unproductive populations.

In existence for more than fifty years, it can hardly be a coincidence that, with the decline of economically productive prison industries near the turn of the century, state and prison authorities began to expand the use of parole 
as a way of reducing prison populations. While Rothman (1980) would have us believe that developments in parole were due to the ideological agenda of Progressive reformers, Messinger, Berecochea, Rauma, and Berk (1985) contend that, at least in California, it was prison overcrowding, rather than any rehabilitative movement, that prompted parole expansion at this time. Clearly, the theoretical model of the state being employed here suggests that, while an overcrowded prison is problematic, a prison that is both unproductive and overcrowded is cause for alarm.

\section{CONCLUSION}

In this paper I have set out the basis of a state-centered analysis of the history of prison labor regimes, emphasizing the institutionalized self-interest of state managers in the reproduction of both the political state and of capitalism. In doing so, I have criticized recent revisionist writings for having seriously under-analyzed the state and the role of state managers as historical subjects. My alternative view rests on the logic of a form-functionapparatus model which outlines the structuring principles of the liberalcapitalist state and its relationship to the economic and normative spheres society. The history of nineteenth century prisons illustrates the fluctuating, often contradictory nature of state action and policies. My interpretation suggests that the failures and limitations of these practices were not the result of the need for "better planning and administration," but rather were engendered by the self-obstructive nature of the policy-making capacity of the state itself.

To require prisoners to labor was a notion that had almost universal acceptance in the early years of the nineteenth century, for it seemed to satisfy the concerns of all parties. The practice was, according to its advocates, the embodiment of punishment, deterrence, reformation, order, and economic retribution. ${ }^{25}$ Few appeared willing to view these goals as potentially contradictory or as having priority in their application. But the historical evidence suggests that this is precisely what transpired. Given the structural position of the liberal-capitalist state in the political economy, prisons had to be more than just places for "reflection." The state could not justify, ideologically or materially, supporting prisoners in idleness. On the other hand, there can be no doubt that the prison was a disciplinary apparatus or, as Bentham characterized it in 1792, "A mill for grinding rogues honest, and idle men industrious" (quoted in Tannenbaum 1922:152). Teaching recalcitrant citizens the ways of labor and thrift was also in the interest of the state, since a "successful" reformation of the prisoner meant reintegration into market/exchange relations upon release and the assurance of social consensus. The "power to punish," then, was not so much directed by or solely in the interest of particular social class. Rather, it was implemented by the state seeking to guarantee the collective interest of all members of a class society reproduced through capitalist social relations. Accordingly, it was believed that the inter- 
ests of class and state, reformer and administrator, citizen, and even prisoner (according to those in power), were best served when the prison embodied what Michael Hindus has characterized as "a mix of Enlightenment views on the nature of crime and an industrial-era solution to the problem of human weakness" (1980:165).

Acknowledgments: Thanks to John
C. Pock and the anonymous review-
ers for their comments on the paper.

\section{NOTES}

1. Despite this common concern, however, revisionist accounts remain fractured along several fronts ranging from materialist interpretations (Melossi and Pavarini 1982; Platt 1969; Ignatieff 1978; Scull [1977] 1984; Foucault 1977), to more functionalist perspectives (Rothman 1971, 1980).

2. This general problem is taken up in a larger, state-centered analysis of the changing face of institutional social control in the U.S. from 1800 to the present of which this paper is part. See Staples (1991).

3. Mann (1984) argues that, within a state-centered model, the state is an arena and that this is precisely the basis of its autonomy. Society-centered perspectives rarely acknowledge such autonomy.

4. Thus the use of term "factory" is, in essence, a metaphor for production organized around capitalist or quasi-capitalist principles.

5. I consider people who derive their principal occupational, professional, and material existence from the state apparatus as a social class not unlike any other. This class exhibits an internal hierarchical structure of power and interest-from elected politicians to career bureaucrats, to the administrative, technical, and staff personnel of the state apparatus. No matter what their position, state actors are social agents who draw upon the power, authority, and material resources available to them in order to reproduce the state and their place within it. Like other social classes, however, state managers and personnel are rarely united on specific issues or policies. Their interests are often fragmented relative to their location in the state hierarchy and in terms of intra-agency competition for resources, organizational jurisdiction, and professional status.

6. Here the basic organizing principles revolve around the relationship between wage labor and capital and as anchored in civil law. The liberal-capitalist state is primarily a decentralized and localized body. It is dependent on both the presence and continuity of private accumulation through its reliance on materials created in that process and on budgetary resources derived through taxation. Yet, while dependent on private production, the liberalcapitalist state is primarily excluded from directly organizing or coordinating commodity production. This "capitalist-state" is not, however, reducible to capital itself; it is a unique institution, embedded within a wider social formation, possessing power for autonomous action.

7. The term "Accumulative State" is derived from the work of Alan Wolfe (1977) and is used here as a descriptive metaphor of state activities during the period. Wolfe's own theoretical assumptions, however, are more society-centered than statecentered.

8. The principle of laissez-faire, so closely identified with the nineteenth century, became a dominant ideology only after the sufficient growth of private sources of capital.

9. These functions involve, in one way or another, the necessity of autonomous state action in the reproduction of both 
the state itself-in terms of political legitimacy and material power-as well as the wider social formation-in terms of coordinating economic exchange and ensuring the stability of class relations.

10. A contradiction in this sense is an opposing or disjunctive condition to the structuring principles necessary for social reproduction (Giddens . [1979] (1983).

11. "Production regimes" are conceived of as the political regulation of production which may be independent of the organization of production or the labor process. 12. Of course, penal labor did not originate in America; it appeared in the Amsterdam Rasphuis and Spinhuis as early as 1596. One anonymous reviewer suggested that this prior development calls into question my attempt to link the appearance of production-oriented penal labor schemes to the rise of the liberal-capitalist state. Yet, I would argue, consistent with a "world-systems" viewpoint that, indeed, capitalism had already taken a foothold in the Dutch city at this time, and, while considered by many a "weak" state, the United Provinces consisted of a "political elite which held ... power over taxation, justice, and the local economy" (Braudel [1979] 1986:196).

13. From Vaux (1826), Notices of the Original and Successive Attempts to Improve the Discipline of the Prison at Philadelpinia and to Reform the Criminal Code of Pennsylvania, as quoted in Barnes (1927:87-91).

14. Report of the Commissioners on the Penal Code (1828:19).

15. Of course, data on the performance of prisons industries must be treated with caution, given the incentive of officials to inflate figures. Yet, while the prisons may not have made an actual profit, it seems clear from the available sources that state appropriations to the institutions did diminish when private contractors were involved.

16. Annual Report of the Inspectors of the Eastern Penitentiary (1855:8-9).
17. Annual Report of the Inspectors of the Eastern Penitentiary (1880:7).

18. Annual Report of the Inspectors of the Eastern Penitentiary (1837:5).

19. The Report of the Prison Investigating Committee, 1830. [Reports of the New Jersey Legislature are reproduced in their entirety in Barnes (1918). This material is on pp. 396-425.]

20. Report of the Joint Committee of Council and Assembly on the Erection of the New State Prison (in Barnes 1918:441).

21. Annual Report of the Inspectors of the Western Penitentiary (1867:8).

22. See the Texas Penitentiary Committee, Report of Findings (1913).

23. Annual Report of the Inspectors of the Eastern Penitentiary (1884:10-11).

24. Annual Report of the Inspectors of the Eastern Penitentiary (1880:7).

25. For a contemporary example of this phenomenon see Staples (1986).

\section{REFERENCES}

Annual Report of the Inspectors of the Eastern Penitentiary. 1837-1880. Philadelphia.

Annual Report of the Inspectors of the Western Penitentiary. 1867. Philadelphia.

Barnes, Harry E. 1918. A History of the Penal, Reformatory and Correctional Institutions of the State of New Jersey. Trenton: MacCrellish and Quigley.

1927. The Evolution of Penology in Pennsylvania: A Study in American Social History. Indianapolis: Bobbs-Merrill.

Beaumont, Gustave de and Alexis de Tocqueville. 1833. On the Penitentiary System of the United States and Its Application in France. Trans. Francis Lieber. Philadelphia: Carey, Lea, and Blanchard.

Braudel, Fernand. [1979] 1986. The Perspective of the World: Civilization and Capitalism, 15th-18th Century (Vol. 3). New York: Harper and Row.

Burawoy, Michael. 1983. "Between the Labor Process and the State: The Changing Face of Factory Regimes Under Ad- 
vanced Capitalism." American Sociological Review 48:587-604.

Clark, Gordon and Michael Dear. 1984. State Apparatus: Structures and Language of Legitimacy. Boston: Allen and Unwin.

Cohen, Stanley and Andrew Scull. 1983. Social Control and the State. New York: St Martin's.

Commons, John. [1921] 1966. History of Labor in the United States, 1895-1932. New York: Kelley.

Dumm, Thomas. 1987. Democracy and Punishment: Disciplinary Origins of the United States. Madison, WI: Wisconsin University Press.

Foucault, Michel. [1975] 1979. Discipline and Punish: The Birth of the Prison. Trans. A.M. Sheridan. New York: Vintage.

Giddens, Anthony. [1979] 1983. Central Problems in Social Theory: Action, Structure and Contradiction in Social Analysis. Berkeley and Los Angeles: University of California Press.

Gill, H.B. 1931. "The Prison Labor Problem." Pp. 83-101 in Prisons of Tomorrow, edited by E.H. Sutherland and T. Sellin. Philadelphia: The Annals of the American Academy of Political and Social Science.

Hindus, Michael. 1980. Prison and Plantation: Crime, Justice, and Authority in Massachusetts and South Carolina, 17671878. Chapel Hill: University of North Carolina Press.

Ignatieff, Michael. 1978. A Just Measure of Pain: The Penitentiary in the Industrial Revolution, 1750-1850. New York: Pantheon.

Ives, George. 1914. A History of Penal Methods. New York: Stokes.

Lewis, Orlando. [1922] 1967. The Development of American Prisons and Prison Customs, 1776-1845. Albany: Prison Association of New York.

Lowman, John., Robert Menzies, and T.S. Palys. 1987. "Introduction: Transcarceration and the Modern State of Penality." Pp. 1-28 in Transcarceration: Essays in the Sociology of Social Control, edited by J. Lowman, R.J. Menzies, and T.S. Palys. Aldershot, UK: Grower.

Mann, Michael. 1984. "The Autonomous Power of the State: Its Origins, Mechanisms and Results." Archives européennes de sociologie 25:185-213.

McKelvy, Blake. [1936] 1977. American Prisons: A History of Good Intentions. Montclair, NJ: Patterson Smith.

Melossi, Dario and Massimo Pavarini. [1978] 1981. The Prison and the Factory: Origins of the Penitentiary System. Trans. G. Cousin. Totowa, NJ: Barnes and Noble.

Messinger, S., J.E. Berecochea, D. Rauma, and R.A. Berk. 1985. "The Foundations of Parole in California." Law and Society Review 19:69-106.

Mittleman, E.B. [1921] 1966. "Prison Labor in the United States." Pp. 327-354 in A History of Labor in the United States, 18951932, edited by J.R. Commons. New York: Kelley.

Mohler, H.C. 1925. "Convict Labor Policies." Journal of Criminal Law and Criminology 4:557-573.

National Prison Association. 1884. First Annual Report. New York: C.G. Burgoynr's. 1887. Proceedings of the National Prison Congress of 1886. Chicago: Donnelley and Sons.

O'Connor, James. 1973. The Fiscal Crisis of the State. New York: St. Martin's.

Platt, Anthony. 1979. The Child Savers. Chicago: The University of Chicago Press.

Robinson, Louis. 1931. Should Prisoners Work? Philadelphia: Winston.

Rothman, David. 1971. The Discovery of the Asylum: Social Order and Disorder in the New Republic. Boston: Little, Brown.

1980. Conscience and Convenience:

The Asylum and Its Alternatives in Progressive America. Boston: Little, Brown.

Schneider, David and Albert Deutsch. 1941. The History of Public Welfare in Nerv York State, 1867-1940. Chicago: Univer- 
sity of Chicago Press.

Scull, Andrew. [1977] 1984. Decarceration: Commmunity Treatment and the Deviant $-A$ Radical Viezv. Englewood Cliffs, NJ: Prentice Hall.

Staples, William G. 1986. "Restitution as a Sanction in Juvenile Court." Crime and Delinquency 32:177-185. 1987. "Technology, Control, and the Social Organization of Work at a British Hardware Firm, 1791-1891." American Journal of Sociology 93:62-88.

1991. Castles of Our Conscience:

Social Control and the American State, 18001985. Cambridge, UK: Polity Press; and New Brunswick, NJ: Rutgers University Press.

Texas Penitentiary Committee. 1913. Report of Findings. Austin.

Tannenbaum, Frank. 1922. Wall Shadows: A Study in American Prisons. New York: G.P. Putnam's Sons.
U.S. Bureau of the Census. 1960. The Historical Statistics of the United States: Colonial Times to 1957. Washington, DC: U.S. Government Printing Office.

U.S. Department of Labor. 1887. Convict Labor, 1886. Report of the Commission of Labor. Washington, DC: U.S. Government Printing Office.

U.S. Bureau of Labor Statistics. 1925. Convict Labor in 1923. Washington, DC: U.S. Government Printing Office.

Vaux, Richard. 1826. Notices of the Original and Successive Attempts to Improve the Discipline of the Prison at Philadelphia and to Reform the Criminal Code of Pennsylvania. Philadelphia.

Wolfe, Alan. 1977. The Limits of Legitimacy. New York: The Free Press.

Zilboorg, G. and Henry, G. 1973. A History of Medical Psychology. New York: W.W. Norton. 